\title{
Treatment of Precocious Puberty with Cyproterone Acetate
}

\author{
Edmond A. Werder, ${ }^{[33]}$ Gertrud Mürset, Milo Zachmann, Charles G. D. Brook, \\ and Andrea Prader \\ Department of Pediatrics, University of Zürich, Kinderspital, Zürich, Switzerland
}

\begin{abstract}
Extract
Cyproterone acetate, an antiandrogenic steroid with inhibitory effects on gonadotropin secretion, was given to 13 girls and 6 boys with precocious puberty for periods of $1-3$ years in a daily dose of $70 \mathrm{mg} / \mathrm{m}^{2}$ body surface area. Treatment was started at a mean chronologic age of 6.65 years in girls and 6.21 years in boys.

No side effects were noted and the compound had a beneficial effect on the clinical signs of precocious puberty with the exception of increased growth velocity. Testicular size remained unchanged during treatment. In one boy high testosterone concentration in plasma was reduced to prepubertal levels.

For analysis of the effect of treatment on growth the standard deviation score method was used. The data for height, bone age, height for bone age, and height prediction were compared with those obtained from 21 girls and 11 boys with precocious puberty who did not receive cyproterone acetate. No significant differences between treatment and control groups were found. It is concluded that cyproterone acetate in the dosage used is without effect on growth and would therefore be expected not to prevent short adult stature in patients with precocious puberty.

\section{Speculation}

From the present study it is evident that cyproterone acetate at the dosage used does not diminish the rate of skeletal maturation, but that with other respects it is effective through its antiandrogenic and gonadotropin-inhibiting properties. This may indicate that in precocious puberty, bone maturation is more sensitive to the action of androgens and less suppressible than the secondary sex characteristics or behavioral changes. Whether earlier treatment and/or higher doses would also inhibit bone maturation remains uncertain.
\end{abstract}

\section{Introduction}

Precocious puberty is a condition with considerable impact on the patient and his family. Unfortunately, there is as yet no satisfactory hormonal treatment; although the development of secondary sex characteristics and menstruation are inhibited to some extent by medroxyprogesterone acetate or chlormadinone ace- tate, the problem of short adult stature has not been solved since these drugs fail to normalize final adult height $[4,5,11,15,21]$.

After antiandrogenic compounds were introduced into clinical medicine, their use seemed indicated in boys with precocious puberty, at a stage when androgen secretion is increased in early childhood. Cyproterone acetate $(1,2-\alpha$-methylene-6-chloro-4,6-pregnadi- 
ene-17- $\alpha$-ol-3, 20-dione-17- $\alpha$-acetate), a steroid which was synthesized by Wiechert and Neumann [26] in 1965, appeared to be applicable to both boys and girls with precocious puberty, inasmuch as animal experiments had demonstrated an inhibitory effect on gonadotropin secretion in addition to its direct antiandrogenic properties [16, 22]. In men its suppressive effect on libido has already been well documented [10 12, 17]. The present report analyzes our experience with cyproterone acetate in the treatment of precocious puberty in both sexes since 1967 .

\section{Patients and Methods}

A diagnosis of precocious puberty was made when the furst pubertal signs appeared before the age of 8 years in girls or 9 years in boys. Thirteen girls and 6 boys formed the treatment group (see Tables I and II). In all treated girls cornification of the basal cells of the vaginal mucosa was demonstrated. Congenital adrenal hyperplasia was excluded in all cases by steroid determinations in urine (normal 17-ketosteroids and pregnanetriol for bone age and absence of pregnanetrio-

Table I. Clinical data for 13 girls with precocious puberty treated with cyproterone acetate ${ }^{1}$

\begin{tabular}{|c|c|c|c|c|c|c|c|c|c|c|c|}
\hline \multirow{3}{*}{ Case } & \multirow{3}{*}{ Type } & \multicolumn{8}{|c|}{ Age at onset, yr } & \multirow{3}{*}{$\begin{array}{l}\text { Therapy with } \\
\text { cyproterone } \\
\text { acetate, CA, yr }\end{array}$} & \multirow{3}{*}{$\begin{array}{r}\text { Adjusted } \\
\text { midparent } \\
\text { height, } \mathrm{cm}^{2}\end{array}$} \\
\hline & & \multicolumn{2}{|c|}{ Pubarche } & \multicolumn{2}{|c|}{ Thelarche } & \multicolumn{2}{|c|}{ Mer.arche } & \multirow{2}{*}{$\begin{array}{l}\text { Appearance } \\
\text { of axillary } \\
\text { hair, CA }\end{array}$} & \multirow{2}{*}{ Acne, CA } & & \\
\hline & & $\mathrm{CA}$ & $\mathrm{BA}$ & $\mathrm{CA}$ & $\mathrm{BA}$ & $\mathrm{CA}$ & $\mathrm{BA}$ & & & & \\
\hline$T M$ & $\mathrm{i}$ & 3.5 & 4.7 & 6.5 & 6.8 & 7.3 & 7.6 & 6.5 & 12.3 & $8.2-12.3$ & 168.7 \\
\hline$S B$ & $\mathrm{i}$ & 7.0 & 10.0 & & & 8.5 & 11.5 & 8.0 & 8.1 & $8.1-10.8$ & 171.7 \\
\hline$H A$ & i & 6.8 & 9.7 & 8.4 & 11.2 & 10.6 & 12.6 & 7.3 & 12.5 & $8.1-10.7$ & 163.7 \\
\hline$S M$ & $\mathrm{i}$ & & & 7.0 & 7.3 & & & 9.8 & 8.3 & $8.3-9.8$ & 152.7 \\
\hline$L K$ & i & & & 7.8 & 10.1 & 9.0 & 11.4 & 9.9 & 10.6 & $8.6->12.2$ & 166.7 \\
\hline$B M$ & $\mathrm{i}$ & & & & & 7.7 & 8.0 & 8.3 & & $8.3->11.2$ & 152.7 \\
\hline$K C$ & A. s. & 0.6 & 0.7 & & & 5.4 & 7.7 & & & $5.8->10.0$ & 163.7 \\
\hline$B E$ & $\mathrm{i}$ & 5.0 & 6.5 & & & 6.9 & 11.0 & & & $6.6->9.3$ & 161.7 \\
\hline$W P$ & i & 2.0 & 2.4 & 1.6 & 3.5 & 2.1 & 4.6 & & & $2.5->6.7$ & 164.7 \\
\hline$R B$ & i (c?), epilepsy & 3.5 & 5.6 & & & 4.1 & 6.8 & 3.9 & & $4.1->5.9$ & 162.7 \\
\hline$W A$ & c: deafness, p. r. & 6.0 & 9.1 & 6.0 & 9.1 & 8.0 & 11.8 & & & $7.8->11.7$ & 159.7 \\
\hline$P M$ & $\begin{array}{l}\text { c: neonatal asphyxia, } \\
\text { p. r. }\end{array}$ & $<6.7$ & & $<6.7$ & & & & $<6.7$ & & $6.8->10.2$ & 151.7 \\
\hline$L A$ & $\begin{array}{l}\text { p. r. } \\
\text { c: spastic quadriplegia, } \\
\text { p. r. }\end{array}$ & & & 3.0 & 5.8 & 3.0 & 5.8 & & & $3.4->8.4$ & 168.7 \\
\hline
\end{tabular}

1 i: idiopathic; A. s.: Albright syndrome; c: cerebral; CA : chronologic age; BA : bone age; p. r.: psychomotor retardation.

2 For explanation see text.

Table II. Clinical data for six boys with precocious puberty treated with cyproterone acetate ${ }^{1}$

\begin{tabular}{|c|c|c|c|c|c|c|c|c|c|c|c|c|c|c|c|c|c|}
\hline \multirow{3}{*}{ Case } & \multirow{3}{*}{ Type } & \multicolumn{8}{|c|}{ Age at onset, yr } & \multicolumn{7}{|c|}{$\mathrm{CA}$ and period of treatment, $\mathrm{yr}$} & \multirow{3}{*}{$\begin{array}{l}\text { Adjusted } \\
\text { midparent } \\
\mathrm{ht}, \mathrm{cm}^{2}\end{array}$} \\
\hline & & \multicolumn{2}{|c|}{ Pubarche } & \multicolumn{2}{|c|}{$\begin{array}{c}\text { Appearance } \\
\text { of axillary } \\
\text { hair }\end{array}$} & \multicolumn{2}{|c|}{$\begin{array}{l}\text { Penis } \\
\text { growth }\end{array}$} & \multicolumn{2}{|c|}{$\begin{array}{l}\text { Testicular } \\
\text { volume } \\
\text { increase }\end{array}$} & \multirow{2}{*}{$\begin{array}{l}\text { Deep } \\
\text { voice }\end{array}$} & \multirow[t]{2}{*}{ Erections } & \multirow{2}{*}{$\begin{array}{c}\text { Mastur- } \\
\text { bation }\end{array}$} & \multirow[t]{2}{*}{ Acne } & \multirow{2}{*}{$\begin{array}{c}\text { Gyneco- } \\
\text { mastia }\end{array}$} & \multirow[t]{2}{*}{ C therapy } & \multirow{2}{*}{$\begin{array}{l}\text { Previous } \\
\text { therapy }\end{array}$} & \\
\hline & & $\mathrm{CA}$ & $\mathrm{BA}$ & $\mathrm{CA}$ & $\mathrm{BA}$ & $\mathrm{CA}$ & $\mathrm{BA}$ & $\mathrm{CA}$ & $\mathrm{BA}$ & & & & & & & & \\
\hline LO & $\mathrm{i}$ & 5.3 & 11.2 & 7.3 & 13.4 & 1.5 & 2.5 & 1.5 & 2.5 & 5.9 & 5.9 & 5.9 & 5.9 & 10.5 & $7.8-11.0$ & $\begin{array}{l}\text { MPA, C (6.0- } \\
7.5)\end{array}$ & \\
\hline$B H$ & $\mathrm{i}$ & 2.5 & 2.5 & 10.4 & 15.3 & 2.5 & 2.5 & 3.4 & 4.0 & 4.0 & 3.4 & 3.4 & 4.9 & 9.1 & $6.4->12.4$ & $\begin{array}{l}\text { MPA, CMA, } \\
\text { EE, C (3.5- } \\
6.4)\end{array}$ & 175.8 \\
\hline$Z J$ & $\mathrm{i}$ & 0.7 & 2.5 & 1.6 & 5.9 & 0.7 & 2.5 & 0.7 & 2.5 & 0.7 & 1.0 & 1.6 & 1.0 & 3.1 & $3.1->9.3$ & $\begin{array}{l}\text { MPA, CMA, } \\
\text { C }(1.6-3.1)\end{array}$ & 178.5 \\
\hline$K T$ & $\mathrm{i}$ & 3.8 & 7.0 & & & 3.6 & 6.4 & 3.6 & 6.4 & & 3.8 & 3.8 & 4.1 & 4.1 & $3.9->7.8$ & & 176.8 \\
\hline$M D$ & $c$ & 9.4 & 9.8 & 13.3 & 15.8 & 9.4 & 9.8 & & & 10.9 & & & 13.8 & 9.8 & $9.7-12.7$ & & 178.8 \\
\hline$K R$ & $\mathrm{c}$ & 5.0 & 10.2 & 5.0 & 10.2 & 5.0 & 10.2 & 5.0 & 10.2 & & 5.0 & & & & $5.2->6.8$ & & 164.0 \\
\hline
\end{tabular}

1: idiopathic; $\mathrm{c}^{7}$ cerebral (hydrocephalus); $\mathrm{CA}$ : chronologic age; $\mathrm{BA}$ : bone age; MPA : medroxyprogesterone acetate; CMA : chlormadinone acetate; EE : ethinylestradiol; $\mathrm{C}$ : cyproterone acetate.

${ }^{2}$ For explanation see text. 
lone). On the basis of previous experience in the human $[10,12]$, the patients were given cyproterone acetate [29] in a dose of $70 \mathrm{mg} / \mathrm{m}^{2}$ body surface area daily by mouth, divided into two equal doses.

The data from patients treated for a minimum consecutive period of 1 year were compared with those from untreated cases of precocious puberty and those treated with other hormonal preparations. For comparison of the clinical results, 9 untreated girls and 1 untreated boy were available (Tables IMI and IV). For growth comparison 12 untreated girls (8 idiopathic, 3 cerebral, 1 Albright syndrome) and 10 untreated boys (8 idio- pathic, 2 cerebral) from the Hospital for Sick Children, London [30] were also included.

Measurements of height were recorded on standard percentile charts [25]. Standard deviation scores (SD scores) [24] were calculated using the data for normal Zürich children [3]. The height SD score at a given chronologic or bone age was calculated by subtracting from the measurement of height the normal mean at the age at which the measurement was taken and dividing this difference by the so. Bone age was determined by the method of Greulich and Pyle [7], corrected for Zürich children [3]. Because at present the

Table III. Clinical data for girls with precocious puberty not treated with cyproterone acetate ${ }^{1}$

\begin{tabular}{|c|c|c|c|c|c|c|c|c|c|c|c|c|}
\hline \multirow{3}{*}{ Case } & \multirow{3}{*}{ Type } & \multicolumn{8}{|c|}{ Age at onset, $\mathrm{y}^{\mathrm{r}}$} & \multirow{3}{*}{ Therapy, CA, yr } & \multirow{3}{*}{$\begin{array}{l}\text { Measured } \\
\text { adult ht, } \\
\mathrm{cm}\end{array}$} & \multirow{3}{*}{$\begin{array}{c}\text { Adjusted } \\
\text { midparent } \\
\mathrm{ht}, \mathrm{cm}^{2}\end{array}$} \\
\hline & & \multicolumn{2}{|c|}{ Pubarche } & \multicolumn{2}{|c|}{ Thelarche } & \multicolumn{2}{|c|}{ Menarche } & \multirow{2}{*}{$\begin{array}{l}\text { Appear- } \\
\text { ance of } \\
\text { axillary } \\
\text { hair, CA }\end{array}$} & \multirow{2}{*}{ Acne, $\mathrm{CA}$} & & & \\
\hline & & $\mathrm{CA}$ & $\mathrm{BA}$ & $\mathrm{CA}$ & $\mathrm{BA}$ & $\mathrm{CA}$ & $\mathrm{BA}$ & & & & & \\
\hline$T M$ & $\mathrm{i}$ & & & & & 3.0 & & & & & & \\
\hline$S G$ & $\mathrm{i}$ & 1.9 & 2.4 & 1.5 & 1.8 & 2.2 & 2.8 & & & & 145.5 & 158.7 \\
\hline$I M$ & i & 3.5 & 7.0 & 2.0 & 3.8 & 6.0 & 10.7 & & & & & \\
\hline$C M$ & $\mathrm{i}$ & & & 3.5 & 6.5 & & & 3.5 & & & & \\
\hline$H E$ & $\mathrm{i}$ & 2.3 & 5.7 & 2.0 & 5.0 & 10.5 & 14.2 & & 8.0 & & 159.8 & 163.7 \\
\hline$K R$ & $\mathrm{i}$ & 4.0 & 4.3 & 3.9 & 4.2 & 10.2 & 11.8 & & & & 138.6 & 156.2 \\
\hline$M C$ & $\mathrm{i}$ & 5.0 & 9.0 & 3.5 & 6.3 & 11.5 & 15.5 & 8.3 & & MPA (8.5-10.4) & 159 & 164.7 \\
\hline$G S$ & $\mathrm{i}$ & 4.0 & 7.2 & 2.0 & 3.3 & 7.2 & 12.5 & 7.1 & 11.2 & $\mathrm{MP}(3.4-4.1)$ & 156.5 & 161.7 \\
\hline$S U$ & $\mathrm{i}$ & 2.8 & 5.5 & 2.3 & 4.5 & 8.9 & 14.0 & 5.8 & & & 157.5 & \\
\hline$B A$ & $\mathrm{i}$ & 3.1 & 5.2 & 3.1 & 5.2 & 4.2 & 7.2 & 6.8 & 6.8 & $\begin{array}{c}\text { MPA, CMA }(4.0- \\
8.4)\end{array}$ & 161.3 & 165.7 \\
\hline$S A$ & c & & & 1.5 & 2.2 & & & & & & & 161.7 \\
\hline
\end{tabular}

${ }_{1}$ i: idiopathic; c: cerebral (hydrocephalus); CA: chronologic age; BA: bone age; MP: medroxyprogesterone; MPA: medroxyprogesterone acetate; CMA: chlormadinone acetate.

${ }^{2}$ For explanation see text.

Table $I V$. Clinical data for boy $(K G)$ with idiopathic precocious puberty not treated with cyproterone acetate

\begin{tabular}{|c|c|c|c|c|c|c|c|c|c|c|c|c|c|c|c|}
\hline \multicolumn{8}{|c|}{ Age at onset, yr } & \multicolumn{6}{|c|}{$\mathrm{CA}$ at onset and period of treatment, $\mathrm{yr}$} & \multirow{3}{*}{$\begin{array}{l}\text { Measured } \\
\text { adult ht, } \\
\mathrm{cm}\end{array}$} & \multirow{3}{*}{$\begin{array}{c}\text { Adjusted } \\
\text { midparent } \\
\mathrm{ht}, \mathrm{cm}^{2}\end{array}$} \\
\hline \multicolumn{2}{|c|}{ Pubarche } & \multicolumn{2}{|c|}{$\begin{array}{l}\text { Appearance of } \\
\text { axillary hair }\end{array}$} & \multicolumn{2}{|c|}{ Growth of penis } & \multicolumn{2}{|c|}{$\begin{array}{l}\text { Increased } \\
\text { testicular } \\
\text { volume }\end{array}$} & \multirow[t]{2}{*}{$\begin{array}{l}\text { Deep } \\
\text { voice }\end{array}$} & \multirow{2}{*}{$\begin{array}{l}\text { Erec- } \\
\text { tions }\end{array}$} & \multirow[t]{2}{*}{$\begin{array}{l}\text { Emis- } \\
\text { sions }\end{array}$} & \multirow{2}{*}{$\begin{array}{c}\text { Mastur- } \\
\text { bation }\end{array}$} & \multirow[t]{2}{*}{ Acne } & \multirow{2}{*}{$\begin{array}{l}\text { MP, MPA, } \\
\text { C therapy }\end{array}$} & & \\
\hline $\mathrm{CA}$ & $\mathrm{BA}$ & $\mathrm{CA}$ & $\mathrm{BA}$ & $\mathrm{CA}$ & $\overline{\mathrm{BA}}$ & $\mathrm{CA}$ & $\mathrm{BA}$ & & & & & & & & \\
\hline 0 & 0 & 5.5 & 13.9 & 1.2 & 3.0 & 1.6 & 4.1 & 1.8 & 1.6 & 8.3 & 2.2 & 1.6 & $1.8-9.3$ & 156.6 & 179.9 \\
\hline
\end{tabular}

${ }^{1} \mathrm{CA}$ : chronologic age; BA : bone age; MP : medroxyprogesterone; MPA : medroxyprogesterone acetate; C: cyproterone.

${ }^{2}$ For explanation see text.

Table $V$. Clinical effects of cyproterone acetate in 13 girls with precocious puberty ${ }^{1}$

\begin{tabular}{|c|c|c|c|c|c|c|c|c|c|c|c|c|c|}
\hline & $T M$ & $S B$ & $\not H A$ & $S M$ & $L K$ & $B M$ & $K C$ & $B E$ & $W P$ & $R B$ & $W A$ & $P M$ & $L A$ \\
\hline Arrest of menstrual bleeding & + & & $(+)$ & & $(+)$ & + & + & $(+)$ & $(+)$ & $(+)$ & $(+)$ & & + \\
\hline Reduction of breast size & $(+)$ & $(+)$ & - & $(+)$ & - & - & + & + & + & + & + & - & + \\
\hline Reduction of pubic hair & + & + & + & - & - & + & & + & + & + & + & + & + \\
\hline Reduction of axillary hair & + & + & + & & & & & & & + & + & + & \\
\hline Disappearance of acne & & $(+)$ & & + & & & & & & & & & + \\
\hline
\end{tabular}

\footnotetext{
$1+:$ marked effect; $(+):$ slight effect; $-:$ no effect.
} 
Zürich standards extend only to 12 years [3], the nearly identical standards of Tanner et al [25] were used in the calculation of height SD score for bone age in all cases.

The tables of Bayley and Pinneau [1] were used in the prediction of adult height. Where possible, the predicted or measured adult height of an individual was compared with the expected height calculated from the height of the parents ("target height") [23].

Table VI. Clinical effects of cyproterone acetate in six boys with precocious puberty ${ }^{1}$

\begin{tabular}{lcccccc}
\hline \multicolumn{1}{c}{ Decrease in } & $L O$ & $B H$ & $Z J$ & $K T$ & $M D$ & $K R$ \\
\hline Size of penis & - & + & & + & + & + \\
Pubic hair & $(+)$ & - & - & + & - & + \\
Axillary hair & + & & + & & & + \\
Body hair & & & + & & - & \\
Acne & + & + & + & + & & \\
Masturbation & + & + & + & + & & \\
Erections & + & $(+)$ & $(+)$ & + & + & + \\
Emissions & & & + & & & \\
Depth of voice & - & & - & & - & \\
\hline
\end{tabular}

$1+$ : marked effect; (+): slight effect; $-:$ no effect.
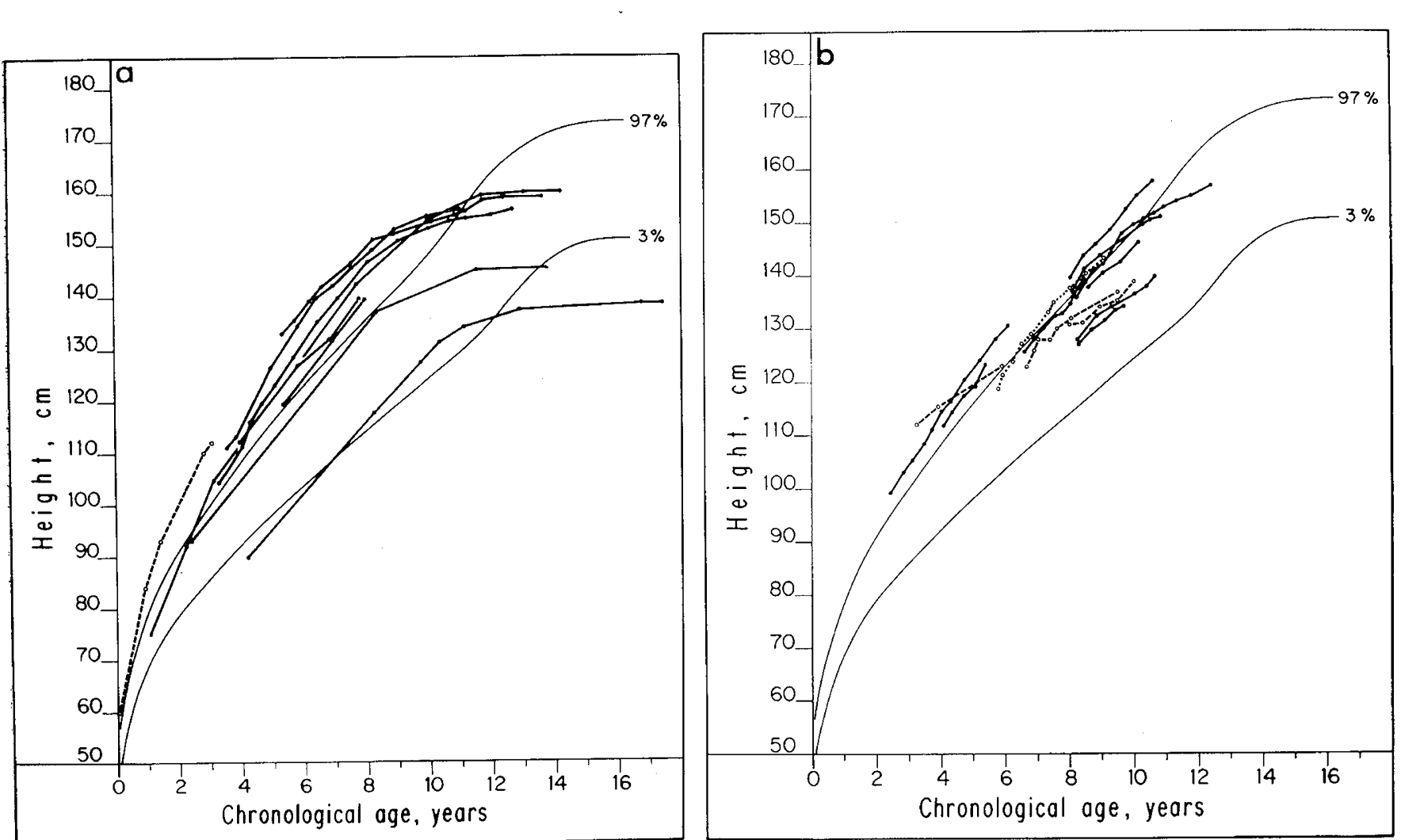

The mean parental height was adjusted for the sex of the child by adding $12.5 \mathrm{~cm}$ to the height of the mother before calculating the mean in the case of a the father in the case of a girl, $12.5 \mathrm{~cm}$ being the

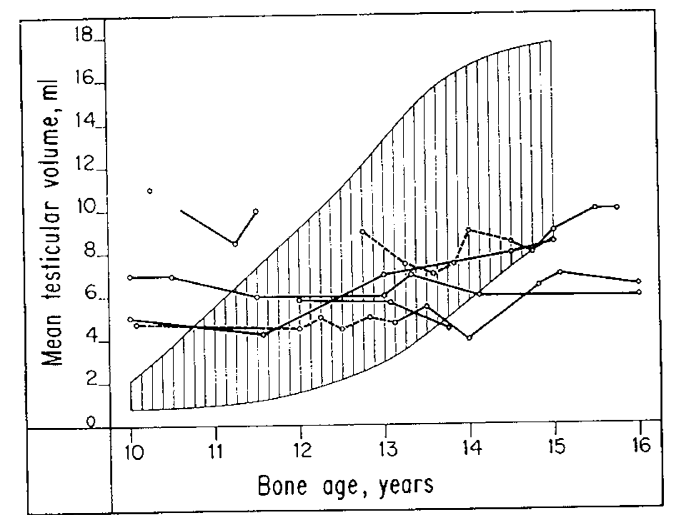

Fig. 1. Testicular volume (mean of right and left side) correlated hormonal treatment; shaded area represents normal testicular volume [28]. boy, and by subtracting $12.5 \mathrm{~cm}$ from the height of with bone age. - - with cyproterone acetate; ---: with other
Fig. 2. a: height of untreated girls. during cyproterone acetate treatment. syndrome. 

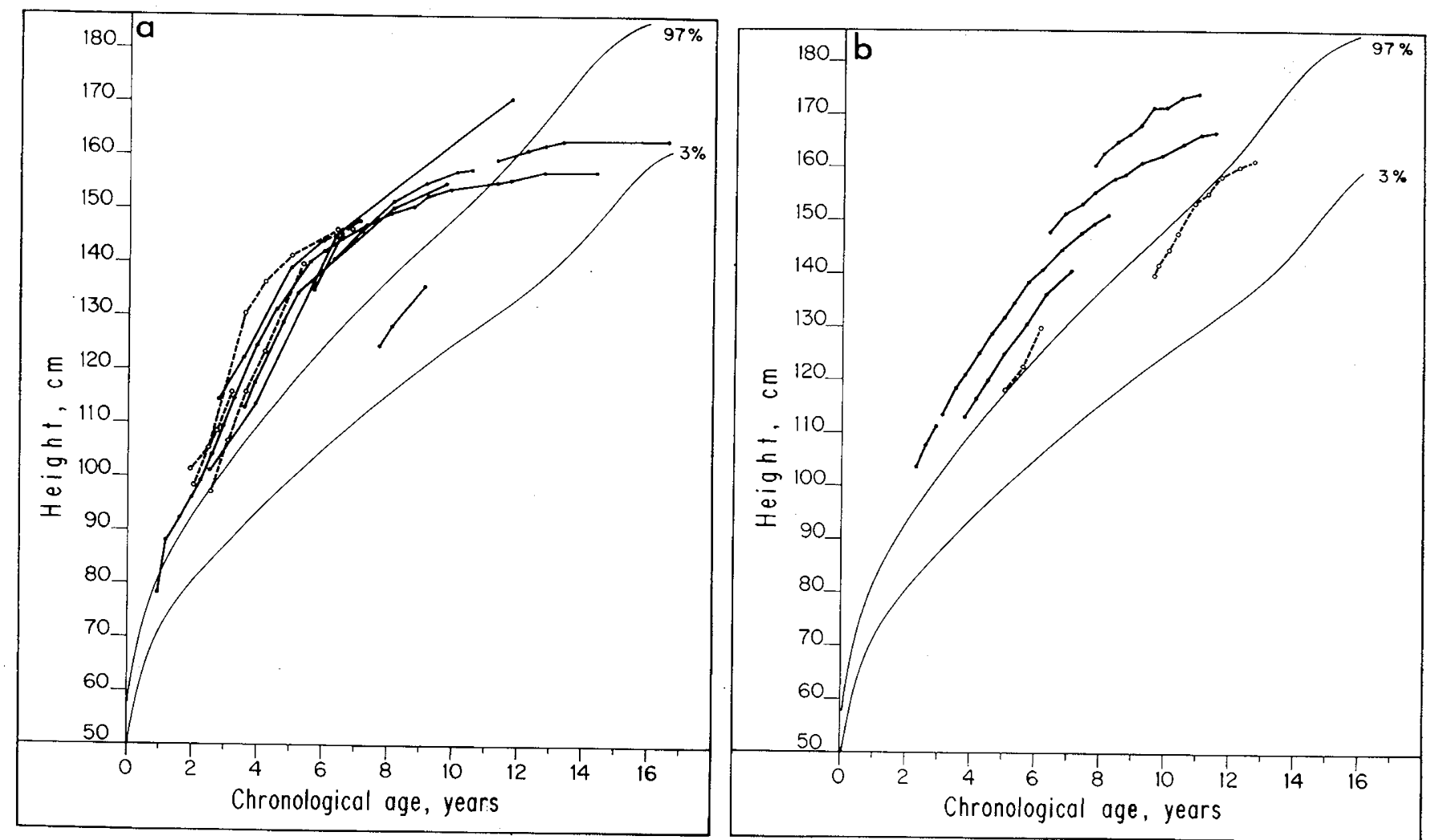

Fig. 3. a: height of untreated boys. during cyproterone acetate treatment.

- - idiopathic precocious puberty; $\bigcirc---\bigcirc$ : cerebral precocious puberty. $b$ : height of boys difference between men and women on their respective 50 th percentiles. In order to obtain the SD score of the predicted or measured adult height, the difference between this and the "target height" was divided by the appropriately reduced SD of $4.25 \mathrm{~cm}$ [23]. Testicular volumes were compared to normal Zürich standards [28].

\section{Results}

\section{Clinical Effects}

The clinical response to treatment in 13 girls is summarized in Table V. Menstruation ceased in four girls and was partially suppressed in two who continued to have occasional spotting. Five of the seven girls who were premenarchal at the start of treatment had rare vaginal bleeding during therapy. A reduction in breast size was noted in nine cases. Reduction in pubic and axillary hair was observed in most cases and acne disappeared or diminished when present. The clinical effects in the six boys are shown in Table VI. The size of the penis decreased in most cases; pubic hair decreased in three boys; axillary hair and acne

definitely decreased or disappeared when present at the start of treatment. Cyproterone acetate had a suppressive effect on sexuality in all cases. It did not reverse deepening of the voice. Testicular volumes are shown in Figure 1. They remained unchanged during therapy.

\section{Effects on Growth}

Figures $2 a$ and $3 a$ show the course of linear growth in untreated cases of precocious puberty; an abnormal growth spurt caused maximal deviation of height at about 8 years in girls and 6 years in boys. After this age, statural growth decreased and stopped after epiphyseal fusion at around 12 years in girls and 10 years in boys. Linear growth during cyproterone acetate treatment is represented in Figures $2 b$ and $3 b$. There is no obvious difference between the growth of treated and untreated patients.

Figure 4 shows the height SD score for chronologic age. The mean of the individual values of the treated cases was centered on the mean chronologic age at the start of treatment, which was 6.65 years for girls and 6.21 years for boys. Thus, the values to the right of 
the vertical axis represent years of therapy. Untreated cases were plotted as a group at their actual chronologic ages. The mean height SD score for treated cases increased both for boys and girls and that for untreated cases fell, but none of the differences between the groups reached statistical significance at the $5 \%$ level.

Figure 5 shows the bone age SD score in the two groups. Both girls and boys in the untreated groups had more advanced bone ages at the time of start of treatment than the treated patients, but cyproterone acetate did not reduce the excessive bone age advancement.

In 18 untreated girls, for whom these data were available, the difference of the mean height sD score for bone age at the start of observation and at a mean time
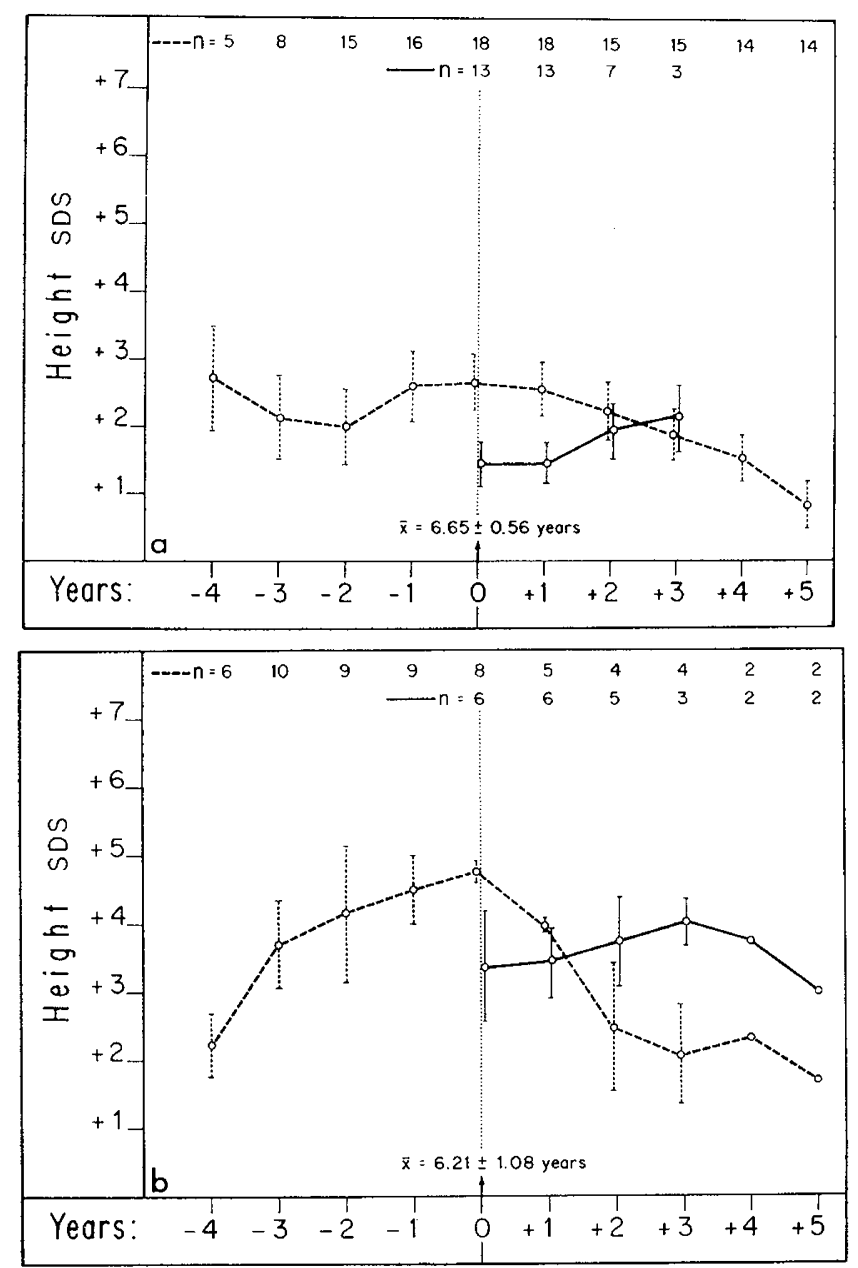

Fig. 4. a: height in girls expressed in sD score $(S D S) \pm$ sem. with cyproterone acetate; ---: without cyproterone acetate. $b$ : height in boys expressed in SD score $(S D S) \pm$ SEM. - - with cyproterone acetate; - - - : without cyproterone acetate.
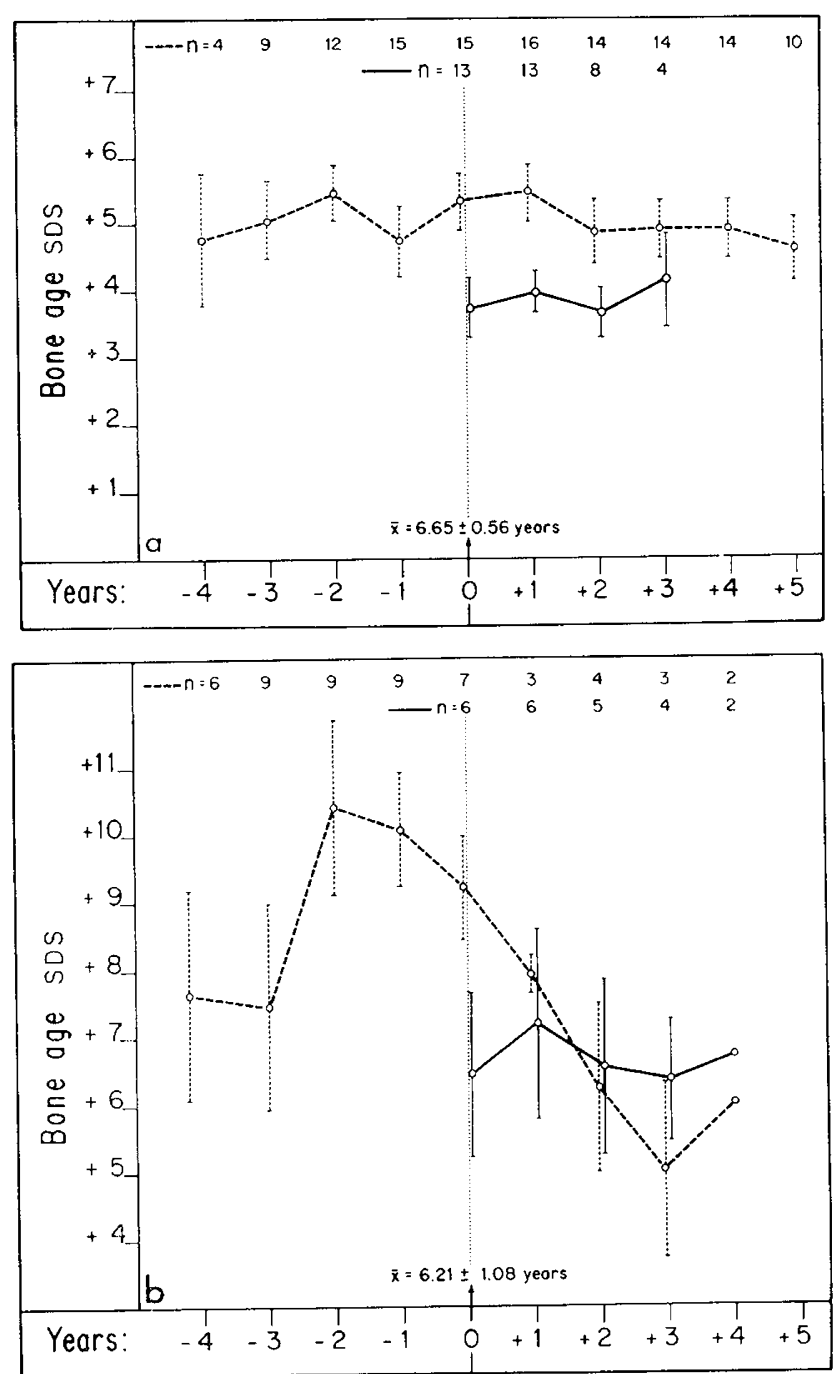

Fig. 5. Bone age in girls expressed in sD score $(S D S) \pm$ sEM. with cyproterone acetate; ---: without cyproterone acetate. Differences between the groups at 0 and +1 year are significant $(0.01<P<0.05)$, at +2 and +3 years, insignificant $(P>0.05)$. $b$ : bone age in boys expressed in SD score $(S D S) \pm$ sEM. - - : with cyproterone acetate; ---: without cyproterone acetate. Differences between the groups at 0 to +3 years are statistically insignificant $(P>0.05)$.

of 6.7 years later was +0.07 (Table VII); in the untreated boys it was -0.29 over 3.5 years. The comparable figures in the treated groups were -0.24 over 2.6 years in girls and -0.27 over 3.4 years in boys. None of these values differ significantly either from 0 or from each other. Untreated boys and girls had an earlier onset of puberty than treated cases (Table VII).

Figure 6 shows the deviation of height prediction from "target height" according to parental stature in the two groups over the years. No difference was 
Table VII. Effect of cyproterone acetate on height for bone age in children with precocious puberty

\begin{tabular}{|c|c|c|c|c|c|c|}
\hline \multirow{2}{*}{ Cases } & \multirow{2}{*}{ No. } & \multirow{2}{*}{$\begin{array}{l}\text { Chronologic age at diagnosis } \\
\text { or start of treatment, } \mathrm{yr}^{1}\end{array}$} & \multirow{2}{*}{$\begin{array}{l}\text { Length of follow-up or } \\
\text { treatment, } \mathrm{yr}^{1}\end{array}$} & \multicolumn{3}{|c|}{ Mean height sp score for bone age \pm SEM } \\
\hline & & & & $\begin{array}{l}\text { At diagnosis or start } \\
\text { of treatment }\end{array}$ & At time of analysis & Difference \\
\hline \multicolumn{7}{|l|}{ Girls } \\
\hline Untreated & 18 & $5.09(1.89-8.89)$ & $6.73(2.70-11.16)$ & $-1.53 \pm 0.26$ & $-1.46 \pm 0.28$ & $+0.07 \pm 0.29$ \\
\hline Treated & 13 & $6.65(2.44-8.56)$ & $2.57(1.37-4.13)$ & $-1.28 \pm 0.29$ & $-1.52 \pm 0.32$ & $-0.24 \pm 0.22$ \\
\hline \multicolumn{7}{|l|}{ Boys } \\
\hline Untreated & 11 & $4.30(0.93-11.31)$ & $3.48(0.87-8.91)$ & $-1.95 \pm 0.40$ & $-2.24 \pm 0.40$ & $-0.29 \pm 0.42$ \\
\hline Treated & 6 & $6.21 \quad(3.14-9.66)$ & $3.39(1.13-5.07$ & $-1.44 \pm 0.63$ & $-1.71 \pm 0.57$ & $-0.27 \pm 0.39$ \\
\hline
\end{tabular}

${ }^{1}$ Mean and range.
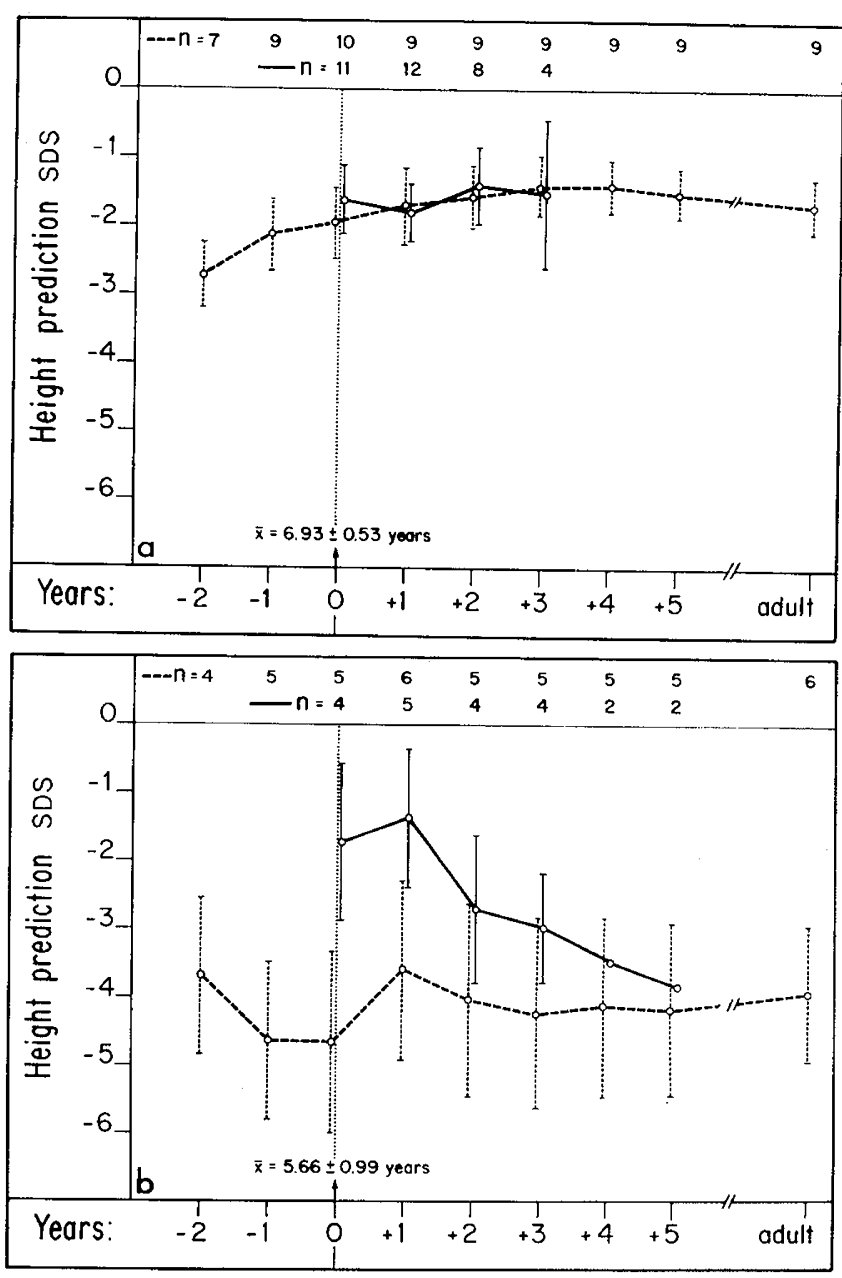

Fig. 6. a: height prediction in girls allowing for parental heights (difference from "target height" [23] expressed in sD score $(S D S) \pm$ SEM). - - : without cyproterone acetate; —-: with cyproterone acetate. $b$ : height prediction in boys allowing for parental heights (difference from "target height" [23] expressed in SD score $(S D S) \pm$ SEM). - - - without cyproterone acetate; - - with cyproterone acetate. found either between or within groups. There was a marked sex difference in the mean deficit of measured adult height, which was $7.2 \mathrm{~cm}$ in girls and $16.8 \mathrm{~cm}$ in boys.

\section{Discussion}

Cyproterone acetate proved to be effective in reducing the clinical manifestations of precocious puberty at a mean dose of $70 \mathrm{mg} / \mathrm{m}^{2}$ daily. No clinical side effects of therapy were noted. In contrast to medroxyprogesterone acetate, which was used in previous years, glucocorticoid effects such as striae and obesity [5] were not observed. Adrenal suppression, which has been described with medroxyprogesterone acetate in man $[14,20]$ and with high doses of cyproterone acetate in animal experiments [6, 27], has not been investigated in our patients, but is unlikely with the dosage used.

The inhibition of testicular growth after the bone age of normal puberty indicates the probable suppression of pituitary gonadotropin secretion, although there are no comparable data from untreated cases. In one boy of the present series, a gradual reduction in plasma testosterone to prepubertal levels $(2,620$ to $140 \mathrm{ng} / 100 \mathrm{ml}$ ) was documented within a year of institution of cyproterone acetate therapy, which also suggests gonadotropin suppression.

In contrast to its beneficial clinical effects, cyproterone acetate had no effect on growth. The aim of treatment would be to increase adult stature by diminishing the advancement of skeletal maturation without impairing linear growth. Thus, the height sD score for bone age should improve. In fact, no significant differences between treatment and control groups were found, and there was no effect on height prediction. Height SD score for bone age is effectively a measure of height prediction. The observed difference in age of onset of puberty between treated and untreated groups is irrelevant because of the reported poor correlation with adult height [4]. 
Despite the obvious clinical effects, which are attributed to the antigonadotropin and antiandrogenic properties of the drug, there is no evidence of a delaying effect on bone maturation. This is at variance with previous reports $[2,8,13,19]$. We attribute this to three factors: we have analyzed data from a larger number of patients over a prolonged period of time, a large control group clarifying the natural history of precocious puberty has been included, and different analytic methods have been used.

Our findings are somewhat contradictory to observations from animal experiments: in normal rats, cyproterone acetate retarded cartilage ossification, but led ultimately to decreased bone length [9] and in testosterone-treated rats, short final length was prevented by the simultaneous administration of cyproterone acetate [9]. In this respect, it is of interest that height prediction in untreated patients does not change significantly after diagnosis and that growth and skeletal maturation after this time proceed concomitantly. This and the experience with rats may indicate that the desired inhibiting effect on bone maturation might possibly be obtained by earlier and/or more vigorous treatment only.

It is concluded that cyproterone acetate in a daily dosage of $70 \mathrm{mg} / \mathrm{m}^{2}$ has no major advantage in comparison with drugs used previously such as medroxyprogesterone acetate. Both drugs have considerable beneficial effects on the clinical signs of precocious puberty, but are without demonstrable effects on growth. Although the effects of cyproterone acetate on the gonads seem to be fully reversible in men [18], experience in females and in boys is still limited.

\section{Summary}

Cyproterone acetate, an antiandrogenic compound with inhibitory effect on the gonadotropin secretion, was administered to 13 girls and 6 boys with precocious puberty for periods of 1 year to more than 3 years in a daily dose of $70 \mathrm{mg} / \mathrm{m}^{2}$ by mouth. This drug proved to have beneficial effects on the clinical signs of precocious puberty and no side effects were noted. The effects on growth were analyzed by comparing the data of height, bone age, height for bone age, and height prediction in treated cases with those obtained from 21 girls and 11 boys with precocious puberty who did not receive cyproterone acetate. Inasmuch as no differences were found, it is concluded that cyproterone acetate in the dosage used is without effect on growth.

\section{References and Notes}

1. Bayley, N., and Pinneau, S. R.: Tables for predicting adult height from skeletal age: Revised for use with the GreulichPyle standards. J. Pediat., 40: 426 (1952).

2. Bossi, E., ZurbrüGg, R. P., AND Joss, E. E.: Improvement of adult height prognosis in precocious puberty by cyproterone acetate. Acta Paediat. Scand., 62: 405 (1973).

3. Budliger, H., Ferrandez, A., Rumpf, U., and Perret, C.: Zürich longitudinal growth study. Unpublished data.

4. Cloutier, M. D., And Hayles, A. B.: Precocious puberty. Advan. Pediat., 17: 125 (1970).

5. David, M., Bovier-Lapierre, M., and Sempe, M.: Le traitement des pubertés précoces par l'acétate de medroxyprogestérone. Pédiatrie, 27: 623 (1972).

6. Domenrco, A., and Neumann, F.: Wirkung von antiandrogen wirksamen Steroiden auf die Funktion und Morphologie der Nebennieren von Ratten. Symp. Dtsch. Ges. Endokrinol., 12: 312 (1967).

7. Greulich, W. W., AND Pyle, S. I.: Radiographic Atlas of Skeletal Development of the Hand and Wrist, Ed. 2 (Stanford University Press, Stanford, 1959).

8. Helge, H., Weber, B., Hammerstein, J., and Neumann, F.: Idiopathic precocious puberty: Indication for therapeutic use of cyproterone acetate, an antigonadotropic and antiandrogenic substance? (Abstract). Acta Paediat. Scand., 58: 672 (1969).

9. Hertel, P., Kramer, M., and Neumann, F.: Einfluss eines Antiandrogens (Cyproteronacetat) auf Knochenwachstum und Knochenreifung männlicher Ratten. Arzneimittel-Forsch., 19: 1777 (1969).

10. Hoffer, H.: Ueber die Anwendung des Testosteronblockers Cyproteron-acetat (SH 714) bei Sexualdelinquenten und psychiatrischen Anstalts-patienten. Praxis, 57: 221 (1968).

11. Kaplan, S. A., Ling, S. M., ANd IRANI, N. G.: Idiopathic isosexual precocity. Amer. J. Dis. Child., 116: 591 (1968).

12. LAschet, U., ANd LAscher, L.: Antiandrogentherapie der pathologisch gesteigerten und abartigen Sexualität des Mannes. Klin. Wschr., 45: 324 (1967).

13. Ludescher, E., Ramers, K., and Gleispach, H.: Antiandrogenbehandlung bei einem Knaben mit Pubertas praecox. Pädiat. Pädol., 5: 316 (1969).

14. Mathews, J. H., Abrams, C. A. L., and Morishima, A.: Pituitary-adrenal function in ten patients receiving medroxyprogesterone acetate for true precocious puberty. J. Clin. Endocrinol., 30: 653 (1970).

15. Menking, M., Blunck, W., Wiebel, J., Stahnke, N., Willig, R. P., AND BIERICH, J.: Ueber Frühreife, IV. Mitteilung: Therapie der Pubertas praecox. Mschr. Kinderheilk., 119: 19 (1971).

16. Neumann, F., von Berswordt-Wallrabe, R., Elger, W., Steinbeck, H., Hahn, J. D., and Kramer, M.: Aspects of androgen-dependent events as studied by anti-androgens. Recent Progr. Hormone Res., 26: 337 (1970).

17. Ott, F., AND Hoffet, H.: Beeinflussung von Libido, Potenz und Hodenfunktion durch Antiandrogene. Schweiz. Med. Wschr., 98: 46 (1968).

18. OTt, F., Hoffet, H., And Hodel, H.: Ueber die Erholung der Spermiogenese nach Behandlung mit Cyproteronacetat. Schweiz. Med. Wschr., 102: 1124 (1972).

19. Rager, K., Huenges, R., Gupta, D., and Bierich, J. R.: The 
treatment of precocious puberty with cyproterone acetate. Acta Endocrinol., 74: 399 (1973).

20. Sadeghi-Nejad, A., Kaplan, S. L., and Grumbach, M. M.: The effect of medroxyprogesterone acetate on adrenocortical function in children with precocious puberty. J. Pediat., 78: 616 (1971).

21. Sigurjonsdottir, T. J., and Hayles, A. B.: Precocious puberty. Amer. J. Dis. Child., 115: 309 (1968).

22. Steinibek, H., AND Neumann, F.: Influence of the antiandrogen cyproterone and its acetate on testicular function, onset of puberty, and bone growth and maturation (Abstract 130). (Excerpta Medica International Congress Series 210, New York, 1970)

23. TAnner, J. M., Goldstein, H., ANd Whitehouse, R. H.: Standards for children's height at ages 2-9 years allowing for height of parents. Arch. Dis. Childhood, 45: 755 (1970).

24. Taniner, J. M., Whitehouse, R. H., Hughes, P. C. R., AND VINCE, F. P.: The effects of human growth hormone treatment for 1-7 years on growth and body composition in 100 children with short stature, due to growth hormone deficiency, low birth weight, inherited smallness, Turner's syndrome and other complaints. Arch. Dis. Childhood, 46: 745 (1971).

25. Tanner, J. M., Whitehouse, R. H., and Takaishi, M.: Standards from birth to maturity for height, weight, height velocity and weight velocity: British children 1965. Arch. Dis. Childhood, 41: 454, 613 (1966).
26. Wiechert, R., ANd NeumanN, F.: Gestagene Wirksamkeit von 1-Methyl- und 1,2- $\alpha$-Methylen-Steroiden. ArzneimittelForsch., 15: 244 (1965).

27. Winkler, G. K., and Harkness, R. A.: The effect of strongly progestational steroid on adrenal function in the guineapig. J. Endocrinol., 30: iii (1964).

28. Zaghmann, M., Prader, A., Kind, H. P., and Hāfliger, H.: Testicular volume during adolescence: Cross-sectional and longitudinal studies. Helv. Paediat. Acta, submitted for publication.

29. Kindly provided by Schering Co., Berlin, Germany.

30. We wish to thank Dr. G. H. Newns for permission to include his cases of precocious puberty.

31. Dr. E. A. Werder was recipient of a grant from the JanggenPöhn-Stifturig, Drs. M. Zachmann and E. A. Werder were recipients of Grants nos. 3.679.71 and KF 1 from the Schweizerischer Nationalfonds zur Förderung der wissenschaftlichen Forschung, and Dr. C. G. D. Brook was supported by the Wellcome Trust.

32. This work was prepared with the assistance of Mr. and Mrs. Adank, Mrs. B. Manella, and Mrs. C. Waghorn.

33. Requests for reprints should be addressed to: E. A. WERDER, M.D., Department of Pediatrics, University of Zürich, Kinderspital, Steinwiesstrasse 75, 8032 Zürich, Switzerland.

34. Accepted for publication November 21, 1973. 